\title{
A Study on the Matching between the Straight Wing Non-articulated Vertical Axis Wind Turbine and the New Wind Turbine Generator
}

\author{
Takasi Siota Member (TOYODENKI SEIZO K.K., siota@toyodenki.co.jp) \\ Tsutomu Isaka Member (TOYODENKI SEIZO K.K., isakat@toyodenki.co.jp) \\ Takashi Sano Non-member (TOYODENKI SEIZO K.K., sanot@toyodenki.co.jp) \\ Kazuichi Seki Member (Tokai University, kalmond@fusha.org)
}

Keywords: wind turbine generator, permanent magnet generator, control circuit less, rectifier, matching

Recent years, wind turbine generator system rapidly spreads as natural energy to play a role of prevention of global warming.

In the wind turbine generator system, there are substantial problems such as the maximum power of the wind turbine cannot be obtained under the fluctuating wind speed, high in cost and low in annual net electricity production.

The new wind turbine generator optimized for the wind turbine output is presented in order to solve such problems. This generator is using neither the control circuit nor the PWM converter. Hereinafter, we call this new type of the generator "CC-less".

Figure 1 shows main circuit configuration of CC-less. CC-less is comprised of permanent magnet generator with 2 windings which produce different induced voltage effective value, reactor, and rectifier and outputs DC output to load DC voltage power.

To gain maximum output power from wind, so that generator input power characteristic to rotational speed of wind turbine may follow cubic curve of maximum wind turbine output power, it is only necessary to consider electrical loss and produce generator output power.

Figure 2 shows the characteristic image of CC-less. DC output power of W2 winding with more turns starts output from low rotational speed $\mathrm{N} 2$ and by the increase of generator rotational speed becomes output described "No reactor" of Fig. 2. However, when CC-less generator is driven by wind turbine at this condition, the generator torque is larger than wind turbine torque and the wind turbine becomes stall condition. Wind turbine rotational speed stops at near rotational speed N2 of Fig. 2 and is not increased.

When by inserting reactor in W2 winding in series the current is controlled, output power becomes the output described "Series reactor" of Fig. 2 and W2 winding can play a role of output of low wind speed range of wind turbine cube curve output power characteristic.

In addition, DC output power of W1 winding with less turns starts output from middle rotational speed N1 and by the increase of rotational speed the large output power can be produced. W1 winding

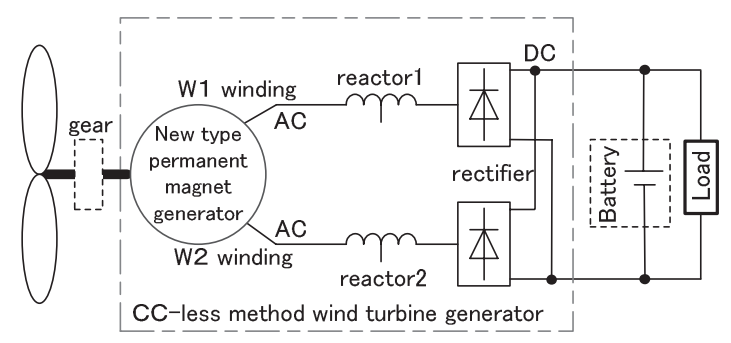

Fig. 1. Main circuit configuration of CC-less can play a role of output of high wind speed range.

The winding number of generator and the inductance value of reactor 1 and 2 shown in Fig. 1 are designed by the use of electromagnetic field analysis software. Consequently, CC-less output which is the total of DC output of W1 winding and W2 winding can be roughly cubic output characteristic along maximum wind turbine output power.

CC-less confirmation device was produced experimentally. The result of the matching test between this CC-less and straight wing non-articulated vertical axis wind turbine under fluctuating wind speed is shown in Fig. 3. The experiment result was confirmed that the output power of the CC-less is well matched with fluctuating wind turbine output brought by ever-changing wind energy, from low to high wind speed, and the maximum wind turbine output power can be obtained without using PWM converter control.

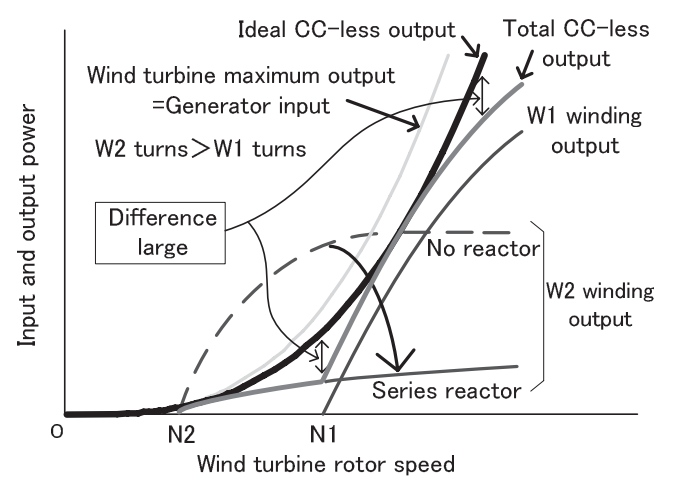

Fig. 2. Characteristic image of CC-less

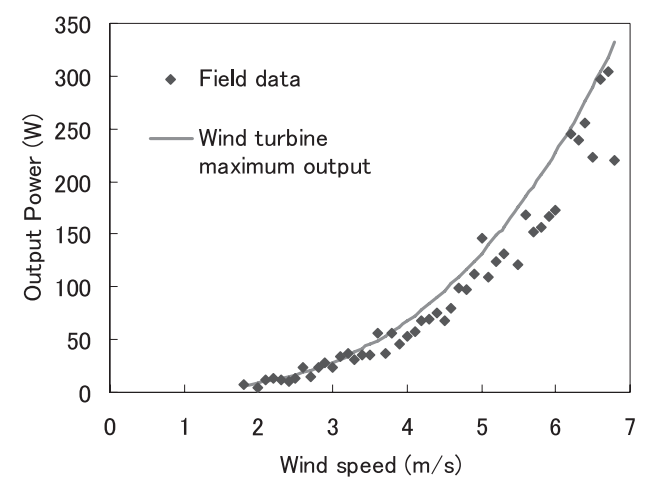

Fig. 3. Result of matching test between straight wing non-articulated vertical axis wind turbine and CC-less 


\title{
直線翼垂直軸型風車と新型風力用発電装置の 整合性に関する研究
}

$\begin{array}{lllll}\text { 正員 塩田 } & \text { 剛* } & \text { 正 員 井坂 } & \text { 勉* } \\ \text { 非会員 佐野 } & \text { 孝* } & \text { 正 員 関 和市** }\end{array}$

\author{
A Study on the Matching between the Straight Wing Non-articulated Vertical Axis Wind \\ Turbine and the New Wind Turbine Generator \\ Takasi Siota*, Member, Tsutomu Isaka*, Member, Takashi Sano*, Non-member, Kazuichi Seki**, Member
}

\begin{abstract}
In the current wind turbine generation system, there are substantial problems such as the maximum power of the wind turbine cannot be obtained under the fluctuating wind speed, high in cost and low in annual net electricity production (due to mismatch between a generator and a wind turbine). A new wind turbine generator optimized for the wind turbine output is presented in order to solve such problems. This wind turbine generator consists of a permanent magnet generator, a reactor and a rectifier, and uses neither a control circuit which requires standby electricity nor a PWM converter having a switching element. By selecting most appropriate combination of the permanent magnet generator having multiple windings and the reactor connected in series with each winding, the maximum output of the wind turbine can be obtained without using a control circuit. The new wind turbine generator was directly coupled with the straight wing non-articulated vertical axis wind turbine (SW-VAWT), and matching of the generator with the wind turbine was examined through field tests. From the test result and review, it has been confirmed that the new wind turbine generator is highly matched with the wind turbine under the fluctuating wind speed.
\end{abstract}

キーワード : 風力発電装置, 永久磁石型発電機, 制御回路レス, 整流器, 整合性

Keywords: wind turbine generator, permanent magnet generator, control circuit less, rectifier, matching

1. はじめに

天然資源の枯渇, 地球温暖化阻止の観点から風力発電は 急速な拡がりを見せている。しかしながら，現在の風力発 電システムに接続される従来の発電装置においては, 以下 のような個々の又は複合した問題点がある。

(1) 変動風速下に㧍いて，常に風車最大出力を取得でき るとは限らない。

(2) 初期コストおよび運用コストが高い。

(3) 年間正味発電量が少ない。特に, 制御回路が必要な 場合には，いつ吹くか分からない風に対しても待機電 力が必要になり,さらに年間正味発電量が減少する。 本論文では, これらの問題点を解決または緩和した発電

\footnotetext{
*東洋電機製造（株）研究センター

于 236-0004 横浜市金沢区福浦 3-8

Technical Research Center, Toyodenki Seizo K.K.

3-8, Fukuura, Kanazawa-ku, Yokohama 236-0004

** 東海大学総合科学技術研究所

干 259-1292 平塚市北金目 1117

Tokai University

1117, Kitakaname, Hiratsuka 259-1292
}

装置は，「風車との整合性が高い」と定義する。 従来の発電装置には，インバー夕方式と整流方式がある。 インバータ方式では, 変動する風速から常に風車最大出力 を得るために, インバータを用いて可変速運転を行ってい る。しかし, インバータ制御回路の制御電源に必要な待機 電力と PWM 変換器のスイッチング損失により, 低風速時 には風車から取得できる最大電力よりも，消費する電力が 多いために正味発電量がマイナスになるという問題がある。 この問題は, 待機電力が発電容量に対して大きな割合を占 める, 小型風力発電システムにおいて特に顕著である。

永久磁石型発電機の出力を整流して直流出力する整流方 式においては, 例えば $10 \mathrm{~m} / \mathrm{s}$ 程度の高風速時に定格出力が 取れるように設計されている。したがって, 風速出現頻度 が高い風速 $5 \mathrm{~m} / \mathrm{s}$ 以下では, 風車は空回り状態であり, そ の風速での風車最大回転数になっても, 発電機出力電圧が 負荷としての直流電源電圧より低いために出力が取り出せ ないという問題がある(1)。

これらの問題点を念頭に置き，特に前記(1)の問題点に着 目して, 新方式発電装置の研究・開発を行った。以下, この 新方式発電装置を CCレス（制御回路レス一Control Circuit 
Less 等) と称する。

CC レスは, 待機電力が必要な制御回路およびスイッチ ング素子で構成される PWM 变換器を用いることなく, 風 車出力に最適化された永久磁石型同期発電機, リアクトル および整流器の組合せ装置である。

このCCレスを直線翼垂直軸型風車に適用して実験を行 い, 前記(1)の問題点に対して, 風車との整合性が高い発電 装置であることが，実験結果より確認された。

本論文では, CC レスの概要, 実験結果, 出力特性向上 策，および適用方法について報告する。

\section{2. 風車最大出力取得方法}

$\langle 2 \cdot 1\rangle$ 原 理 Fig. 1 に受風面積 $5 \mathrm{~m}^{2}$ の直線翼垂直 軸型風車 (SW-VAWT, straight wing non-articulated vertical axis wind turbine）を，Fig. 2 にその風車性能を示す ${ }^{(2)}$ 。

風車は形状が定まると, 出力係数 $\mathrm{C}_{\mathrm{p}}$ と周速比 $\beta$ の関係 が一義的に定まる。

周速比 $\beta$ は(1) 式で与えられる。従って, 各風速におい て, 風車が最大出力を発生する回転数 $N(o p t)$ は, (2) 式で 与えられ，各風速に比例する。

また各風速における風車出力は，(3) 式で与えられる。し たがって，(3) 式に(2) 式を代入し， $\mathrm{C}_{\mathrm{p}}$ に最大出力係数を用い ると，(4) 式のように各風速における風車最大出力 $\mathrm{W}(\max )$ は風車回転数 N の 3 乗に比例する。

$$
\begin{aligned}
& \beta=\frac{2 \pi \times N \times R}{V} \ldots \ldots \ldots \ldots . \\
& N(\text { opt })=\frac{\beta \max \times V}{2 \pi \times R}=K_{1} \times V
\end{aligned}
$$

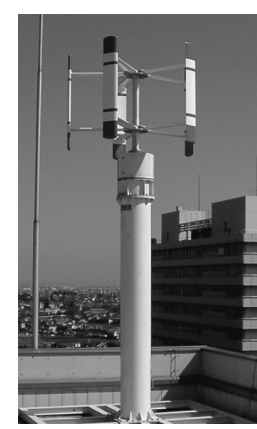

Fig. 1. SW-VAWT system.

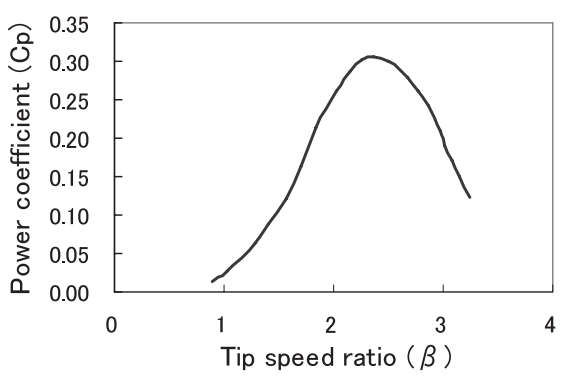

Fig. 2. Power performance of SW-VAWT.

$$
\begin{aligned}
& W=\frac{1}{2} \times \rho \times C p \times A \times V^{3} \\
& W(\max )=K_{2} \times N^{3} \ldots \ldots
\end{aligned}
$$

ここで, $R$ : 風車半径 $[\mathrm{m}], \mathrm{N}$ : 風車回転数 $[\mathrm{rps}], \mathrm{N}(\mathrm{opt})$ : 各 風速 $\mathrm{V}$ における風車最大出力時の回転数 $\mathrm{N}, \mathrm{V}$ : 風速 $[\mathrm{m} / \mathrm{s}]$, $\mathrm{C}_{\mathrm{p}}$ : 出力係数, $\beta$ : 周速比, $\beta \mathrm{max}$ : 出力係数 $\mathrm{C}_{\mathrm{p}}$ が最大と なる周速比 $\beta, \rho$ : 空気密度 $\left[\mathrm{kg} / \mathrm{m}^{3}\right], \mathrm{W}$ : 風車出力 $[\mathrm{W}]$, $\mathrm{W}(\max )$ : 各風速 $\mathrm{V}$ における風車最大出力, $\mathrm{A}$ : 風車受風面 積 $\left[\mathrm{m}^{2}\right], \mathrm{K}_{1}, \mathrm{~K}_{2}$ : 比例定数である。

以下の回転数に関する説明では, 特に断らない限り, 風 車と発電機は損失のないギアで接続されているとし, 風車 回転数のみで説明する。

Fig. 3 に風速をパラメータにした受風面積 $5 \mathrm{~m}^{2}$ の SWVAWT の出力特性と整流方式出力特性例を示す。定常風速 では, 各風速での風車出力と発電機入力との交点が風車の 運転点となる。図中の各風速の最大出力点を繋いだ実線で 示す 3 乗曲線が, 風車の有する最大出力である。

このことから，ギア等の機械損を無視すれば風車出力 = 発電機入力となるので, 風から常に最大出力を得るために は, 風車回転数に対する発電機入力特性が風車最大出力の 3 乗曲線に追従すれば良い。

$\langle\mathbf{2} \cdot \mathbf{2}\rangle$ 従来の発電装置 従来の小型風力発電装置に は, インバータ方式と整流方式がある。インバータ方式に おいては, 発電機のトルク制御による可変速運転によって 風車最大出力取得を実現している ${ }^{(3)}$ が, インバー夕制御回 路の制御電源に必要な待機電力と PWM 変換器のスイッチ ング損失により, 低風速時には風車から取得できる最大電 力よりも，消費する電力が多いために年間正味発電量が少 なくなるという問題がある。

一般的に, 風力発電システムにとっては, 発電装置が負 荷にとって利用しやすい直流電源へ出力するという形態が 良い。このような場合に, 永久磁石型発電機出力に整流器 を接続した整流方式においては, Fig. 3 の点線に示すよう に, 風速出現頻度が高い風速 $5 \mathrm{~m} / \mathrm{s}$ 以下では, 風車回転数

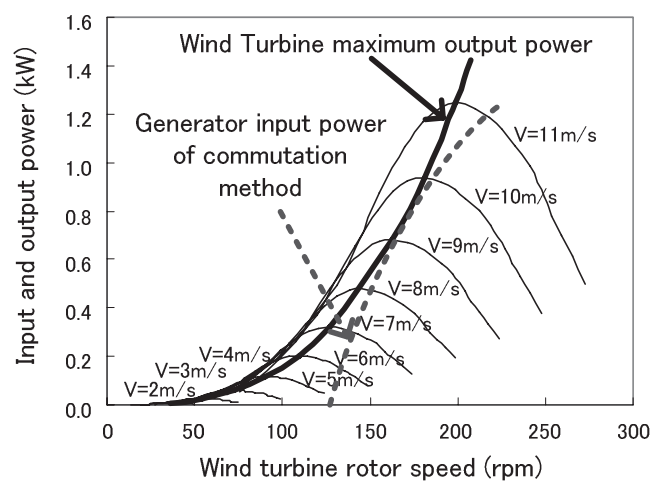

Fig. 3. Maximum output of SW-VAWT and power characteristic of commutation method. 
がその風速での最大回転数となっても, 発電機出力電圧が 負荷としての直流電源電圧よりも低いために出力が取り出 せないという問題がある。

\section{CCレス方式発電装置}

〈3・1〉 CCレス方式の原理風車最大出力を得るため には，(4) 式より，発電機入力が風車回転数に対して 3 乗 特性を有する風車最大出力曲線に追従するように, 電気損 失を考慮したうえで，発電機出力が取り出せれば良い。そ こで CCレスは，制御電源を必要としない受動素子のみで Fig. 3 の実線と点線が重なるように開発した。

〈3・2〉CCレス方式の主回路構成ＣCレスとは，

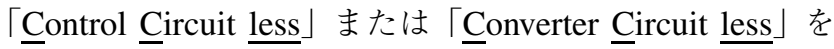
意味し, 多種類の巻線を内蔵して異なる誘起電圧実効值を 発生する永久磁石型発電機, タップ付きリアクトルおよび 整流器の受動素子のみで構成される。このようにCPUや スイッチング素子等の制御電源を必要とする能動素子を使 用していないのが，CCレスの大きな特徵である(4)(5)。

Fig. 4 にCCレスの永久磁石型発電機が 2 種類の巻線を 内蔵する場合の主回路構成例を, Fig. 5 には Fig. 4 に示す CCレスが負荷としての一定直流電源電圧に出力した時の 入出力特性イメージを示す。

〈3·3〉 CCレス方式の負荷ＣCレスは，直流電流を

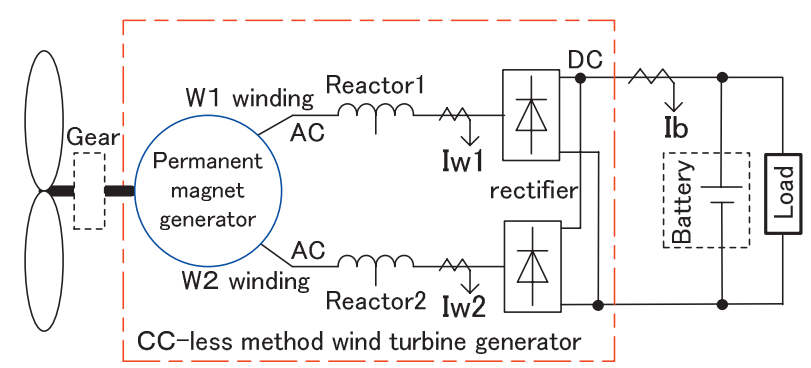

Fig. 4. Main circuit configuration of CC-less.

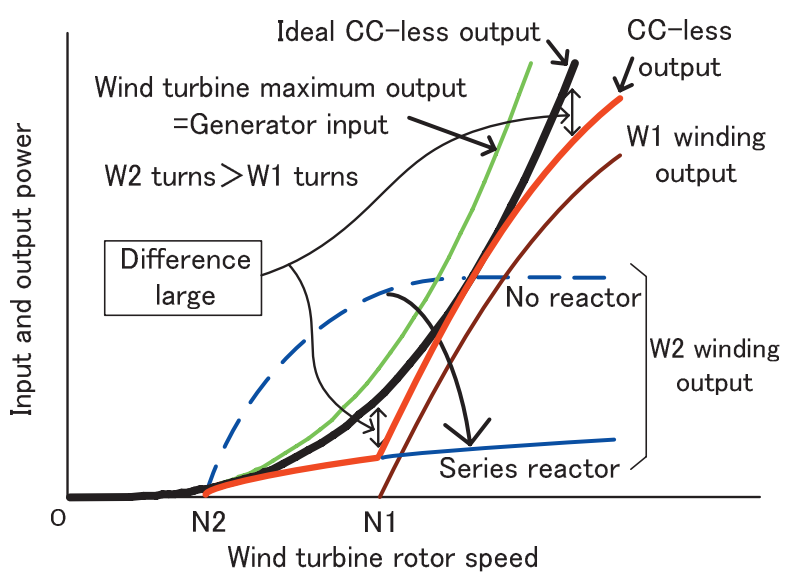

Fig. 5. Characteristic image of CC-less.
出力する装置すなわち一種の可変直流電流源であり，その 直流出力を CCレスとは別の装置によって構成される, 負 荷としての直流電源に出力する。

この負荷としての直流電源は，独立負荷（蓄電池等）で も系統連系負荷 (一定直流電圧制御が可能な連系インバー 夕等) でも CCレスと接続ができる。負荷としての直流電 源電圧がほぼ一定であれば，風が強くなり回転数が増加す ると, CC レス特性に基づいて, 直流出力が回転数に対し て，ほほ 3 乗特性で増加する。

しかしながら，負荷としての直流電源電圧值が大きくな ると, 電流が流れ難くなり, CCレス出力が減少する。逆に 直流電源電圧值が小さくなると CCレス出力が増加し, 増 加し過ぎると風車が失速状態となる。

〈3・4〉多巻線とリアクトルの組合せ効果＼cjkstart永久磁石 型発電機においては, 誘起電圧実効值の大小は, 永久磁石 による磁束の大きさが定まれば，固定子巻線の巻数と発電 機回転数の大小により決まる。したがって，Fig. 5 におい て，巻数の多い W2 巻線の直流出力は，低い回転数 N2 か ら出力を開始し，発電機回転数の上昇により，Fig. 5 の青 色点線で示す “W2 winding output” の “No reactor” のよう な出力になる。しかし，この状態で風車により CCレスの 発電機を駆動しようとすると, 発電機トルクが風車トルク よりも大きくなるので, 風車は失速状態となる。すなわち, 風車の回転数は Fig. 5 の回転数 $\mathrm{N} 2$ 付近に留まり, 上昇し ない。

そこで, W2 巻線に直列にリアクトルを挿入することに より電流を抑制すると, Fig. 5 の青色実線（一部は赤線と重 なっている）で示す “Series reactor”のような出力となり, W2 巻線に風車 3 乗出力特性の低風速域の出力を担わせる ことができる。

また, 巻数の少ない $\mathrm{W} 1$ 巻線の直流出力は, 風車の回転数 が高くなってから出力を開始する。リアクトル 1 は，回転 数の上昇により, 大きな出力を取るために小さなインダク タンス值を持ったリアクトルで構成でき, 内部インダクタ ンスが大きく設計された発電機の場合には, 省略することも 可能である。Fig. 5 の茶色実線で示す “W1 winding output” のように, W1 巻線は主として高風速域の出力を担わせる ことができる。

合計した出力は, Fig. 5 の赤線実線（一部は青線実線と 重なっている）で示す “CC-less output” のようになる。

〈3.5〉CCレス方式の設計方法 CCレスの設計は， 有限要素法十境界要素法による二次元磁界解析を用いて以 下のように行った。まず，Fig. 2 に示すような風車性能を 明らかにして, W1 巻線の発電開始回転数を定格回転数の 半分程度に, W2 巻線の発電開始回転数を定格回転数の $1 / 4$ 程度にそれぞれ決定し, それらの回転数から各巻線の巻数 と永久磁石の磁束の大きさを決定する。その後, 回転数に 対して 3 乗特性を有する風車最大出力特性に近似した CC レス発電機入力となるように，リアクトル 1 および 2 のイ ンダクタンス值を決定する。 
ここで, 発電機の設計にもよるが, 電磁界解析の結果に よるとリアクトル 2 による電圧ドロップは, 定格回転数に おいてW2 巻線無負荷誘起電圧の $75 \%$ 程度の電圧ドロップ が必要である。しかし，これらのリアクトルによる電圧ド ロップは，全て損失になるのではなく遅相無効分が主なの で損失としては小さい。

\section{CCレス方式確認装置}

$\langle\mathbf{4} \cdot 1\rangle$ 飽和リアクトルによる特性改善 受風面積 $5 \mathrm{~m}^{2}$ の SW-VAWT の性能曲線を明確にして風車の最大出力に整 合するように，CCレス方式確認装置を試作した ${ }^{(4)}$ 。

この CC レスの仕様は $200 \mathrm{rpm}, 1.8 \mathrm{~kW}$ 発電機入力, 始 動ピークトルク $1.7 \mathrm{~N}-\mathrm{m}$, 負荷の直流電圧 $24 \mathrm{~V}$ である。

使用した発電機は, アウターロータの別用途電動機 $(3 \phi$, $30 \mathrm{P} ， 36$ スロット，コア外径： $\phi 435$ ，ネオジウム磁石）の 固定子巻線を，1 スロットに 2 種類の巻線を納めるように 改造した。

風車の運用速度範囲は 1 対 3.5 有れば十分である。従っ て, CCレスの発電機においては, 3 種類の巻線を内蔵すれ ば 3 乗出力特性の近似を実現できるが, 製造工数や周辺部 品の増加はコス卜高に繋がる。しかし 2 種類の巻線だと, 特に Fig. 5 の風車回転数 N1 付近と高回転数領域に示すよ うに, 黒色実線で示す理想的な 3 乗 CC レス出力特性と CC レス出力 $(=\mathrm{W} 2$ 巻線出力 $+\mathrm{W} 1$ 巻線出力 $)$ に大きな乘離が 見られる。

そこで, Fig. 4 に示すリアクトル 2 を飽和リアクトル, リ アクトル 1 は非飽和リアクトルとしてCCレス出力の改善 を図った。Fig. 6 は飽和リアクトルの特性例, Fig. 7 はW2 巻線に飽和リアクトルを接続した CC レスの特性イメージ である。風車回転数 $\mathrm{N} 1$ 付近での大きな改善が図れ，理想 的な 3 乗 CC レス出力特性に近づけることができる。この 飽和リアクトルの効果は, Fig. 15 に扔いて, 類似した別の 形式で実証する。

飽和リアクトルは, 非飽和リアクトルと比べてリアクト ル重量が減少するという長所もある。

〈4・2 $\rangle$ CCレス方式確認装置の電気特性 Fig. 8 に CC レスの電気特性試験回路図を示す。電気特性試験では, 駆 動モー夕を可変速して, 負荷としての直流電源電圧 $24 \mathrm{~V}$ 一 定の状態で, 回転数毎の発電機の入力トルクと CCレスの 直流出力を測定した。

Fig. 9 にCCレス方式確認装置の電気特性試験結果を示 す。横軸に発電機回転数, 縦軸に入力 (発電機入力), 出力 （CCレス直流出力）および効率を示す。

この装置は，CCレスの整合性を確認するための装置な ので, 効率には拘らなく設計した。しかしながら，W2 巻 線の電流密度を下げることにより, 出現頻度の高い低風速 域に㧍ける効率を上昇させた。

Fig. 9 の入力は, 発電機回転数に対して, ほほ 3 乗特性 となっているので，この入力特性により，能動的な制御を 行うことなく, 風車より最大出力を取り出せる。

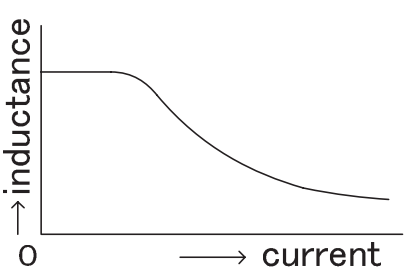

Fig. 6. Characteristic of saturation reactor.

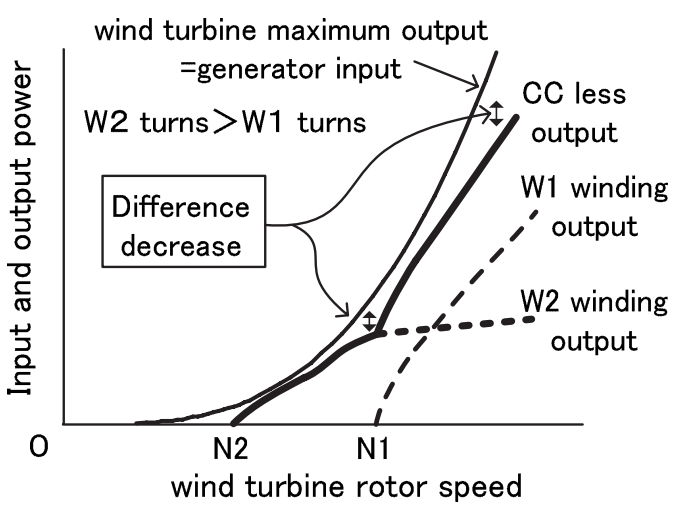

Fig. 7. Characteristic image of CC-less with saturation reactor at $\mathrm{W} 2$ winding.

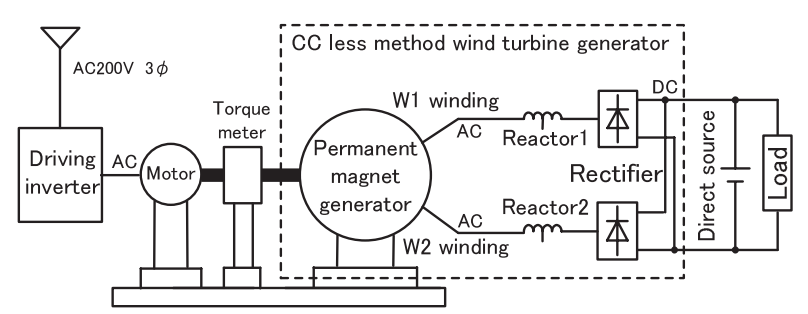

Fig. 8. Electric experiment circuit of CC-less.

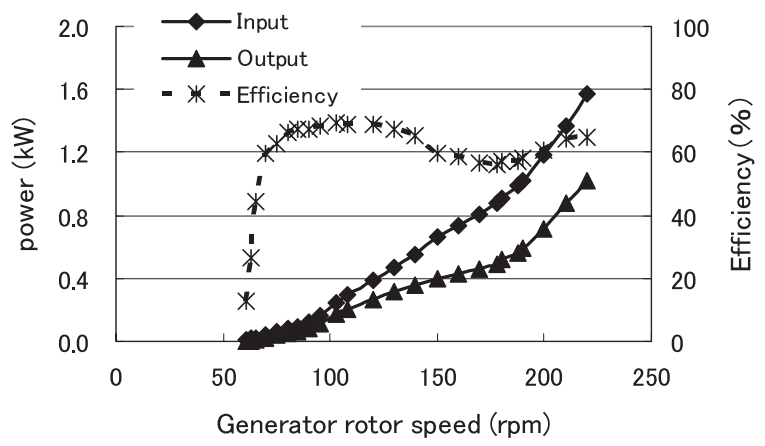

Fig. 9. Electrical characteristics of CC-less.

\section{5. 風車の整合性実験}

Fig. 1 に示すフィールド実験を行っている SW-VAWT に $\mathrm{CC}$ レス方式確認装置を直結して, 風車と $\mathrm{CC} レ$ スの風車 最大出力取得面での整合性について, 検討・実験を行った。

定常的な整合性を確認するために, Fig. 2 の風車性能と, Fig. 9 のCCレスの入力を重ね合わせたものを Fig. 10 に 示す。Fig. 10 より, CCレスの入力は一定風速状態の SWVAWT の最大出力と，良く一致していることが確認できる。

Fig. 11 に SW-VAWT とCCレス方式確認装置との変動 


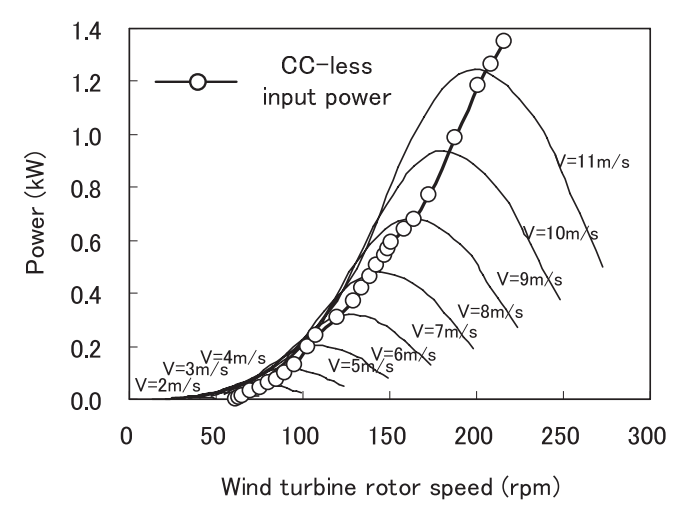

Fig. 10. Matching between SW-VAWT and CC-less.

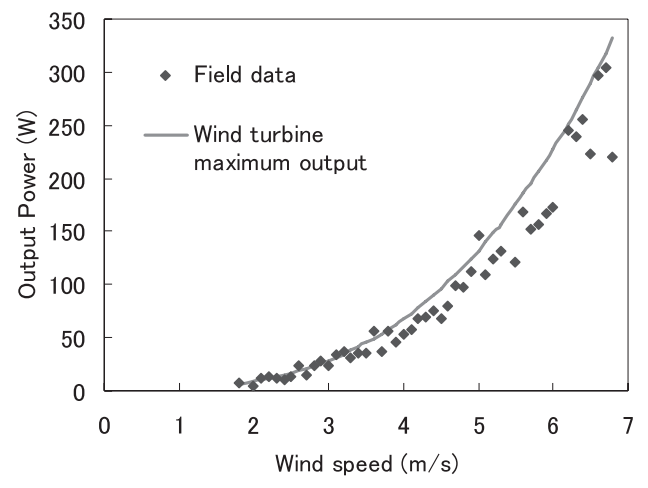

Fig. 11. Result of matching test.

風速下の整合性実験結果を示す。 $2 \mathrm{sec}$ 間隔のサンプリン グ毎に風速挹よび CCレス出力を計測し，各測定值を風速 $0.1 \mathrm{~m} / \mathrm{s}$ 毎に区分けし, その風速毎の $\mathrm{CC}$ レス出力の平均值 を実測值とした。

Fig. 11 より，実測值は装置損失のために実線の風車最大 出力より下回っている。しかし，PWM 変換器による制御 を行わなくとも, CC レス出力は, 低風速から高風速まで, 変動する風エネルギーによる風車出力の変動に対してよく 整合し，風車最大出力が得られることが確認できる。

\section{6. 整流出力に適した永久磁石型発電機}

CC レスに適した同期発電機の回転子構造の定性的な検 討を行った。回転子表面に電流が流れない構造で, 一種類 の固定子巻線を有する同期発電機のモデルは次の電圧方程 式で表される。

$$
\left[\begin{array}{l}
v_{d} \\
v_{q}
\end{array}\right]=\left[\begin{array}{cc}
R+p L_{d} & -\omega L_{q} \\
\omega L_{d} & R+p L_{q}
\end{array}\right]\left[\begin{array}{c}
i_{d} \\
i_{q}
\end{array}\right]+\omega\left[\begin{array}{l}
0 \\
\phi
\end{array}\right]
$$

ここで,

$\mathrm{vd}, \mathrm{vq}$ ：直軸扔よび横軸固定子電圧

id, iq：直軸および横軸固定子電流

$\mathrm{R}$ ：固定子抵抗

$\mathrm{Ld}, \mathrm{Lq}$ ：直軸および横軸インダクタンス

$\phi ：$ 無負荷時の固定子巻線と鎖交する磁束の大きさ

$\omega:$ 回転子電気角速度

$p: \mathrm{d} / \mathrm{dt}$

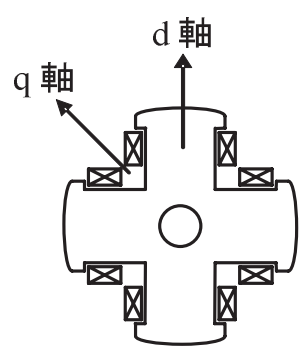

(a) Salient pole with exciting winding

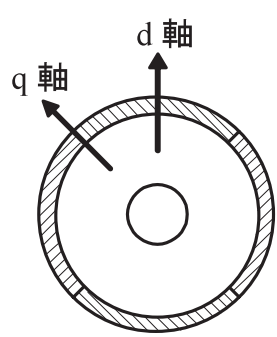

(b) SPM

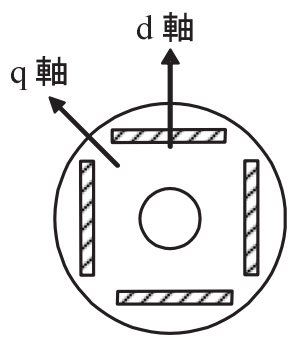

(c) IPM

Fig. 12. Structure of rotor

であり，上式は回転子の磁束方向を $\mathrm{d}$ 軸とし，それと直交 した方向を $\mathrm{q}$ 軸とした dq 座標で表されている。

励磁巻線付き界磁を有する凸極構造，永久磁石を回転子 の表面に張り付ける磁石構造 (SPM)，および永久磁石を回 転子の内部に挿入した埋め込み磁石構造（IPM）に対して, (5) 式による解析が可能である。

Fig. 12 に解析対象とした回転子の代表的な構造を示す。 発電機出力をリアクトルを介さずに，直接，整流して直 流電源に出力した場合のシミュレーションを, 解析ッール PSCAD/EMTDC を用いて以下の条件で行った(6)。

(1) $\mathrm{Ld}<\mathrm{Lq}$ の関係を有する IPM 構造発電機の Ld お よび $\mathrm{Lq}$ の值を基にして, 回転子構造が異なる場合の $\mathrm{Ld} お$ よび Lqを仮定した。

（2） IPM 構造は $\mathrm{Ld}<\mathrm{Lq}(\omega \mathrm{Ld}=40 \%, \omega \mathrm{Lq}=160 \%)$, $\mathrm{SPM}$ 構造は $\mathrm{Ld}=\mathrm{Lq}(\omega \mathrm{Ld}=\omega \mathrm{Lq}=40 \%)$, 励磁巻線 付き界磁を有する凸極構造は $\mathrm{Ld}>\mathrm{Lq} \quad(\omega \mathrm{Ld}=160 \%$, $\omega \mathrm{Lq}=40 \%)$ とし，固定子巻線に鎖交する磁束の大きさ $\phi$ は，どの構造でも変わらないとした。ここで，百分率は相電 圧に対する各リアクタンスの電圧ドロップ分を表している。

（3）発電機の磁気飽和は考慮せず，回転数は定格值一 定とし, 出力先の直流電圧值を変化させた。

Fig. 13 に結果を示す。縦軸は, IPM 構造 $\mathrm{Ld}<\mathrm{Lq}$ の発 電機の定格值を $100 \%$ とした。結果より， Ld $<\mathrm{Lq}$ となる ような IPM 構造の発電機の整流出力は, $\mathrm{Ld}=\mathrm{Lq}$ となる $\mathrm{SPM}$ 構造の発電機よりも大きく, $\mathrm{Ld}>\mathrm{Lq}$ となる励磁巻線 付き界磁を有する凸極構造発電機と比べると，さらに大幅 な出力増が可能である。

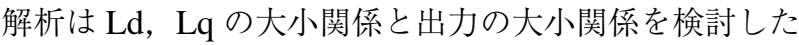
ものであり, 容量や極数等が異なっても解析結果の出力の 大小関係は成立する。 


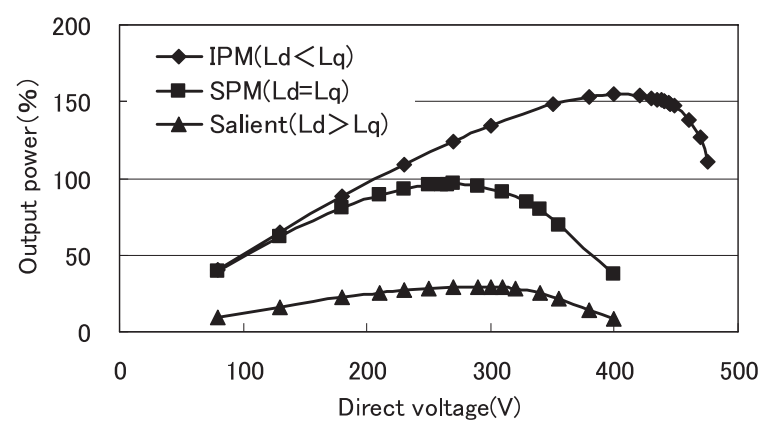

(a) Direct output power

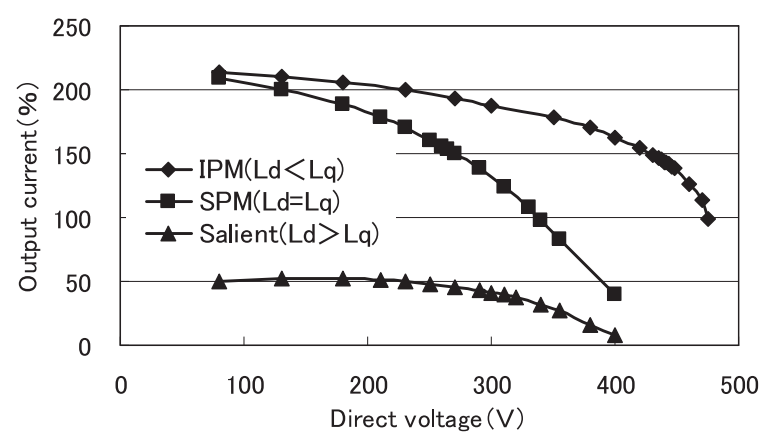

(b) Generator current

Fig. 13. Commutation generating power characteristic based on difference of $\mathrm{Ld}$ and Lq.

\section{7. $2 \mathrm{kWCC} レ ス$}

〈7·1〉 電磁界解析ソフトによる解析 当社汎用の永 久磁石型電動機の生産設備を利用して，安価な CCレス製 作を目指した。Fig. 14 に, その永久磁石型電動機の構造を 示す。

この電動機は，永久磁石を回転子内部に挿入した 6 極の $\mathrm{Ld}<\mathrm{Lq}$ の関係を有する埋め込み磁石構造（IPM）なので, 前章で述べたように，整流出力用発電機として有効である。

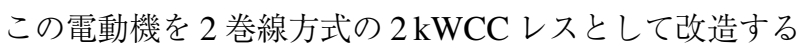
ベく, $2 \mathrm{~kW}$ 風車性能を明らかにし, ギア比および負荷とし ての直流電源電圧值を適正に選ぶことにより，風車から最 大出力が得られるように, $33 \cdot 5\rangle$ 節と同様の電磁界解析を 行った。

Fig. 15 に, 2 kWCC レスの特性解析結果を示す。Fig. 15(a) は, Fig. 4 に示すリアクトル 1 および 2 を非飽和リアクトル とした場合であり，横軸に発電機回転数，縦軸に風車最大出 力 “Maximum power”, CC レス出力 “Output power”, W1 巻線出力 “W1 winding Output”, およびW2 巻線のリアク トル有無における出力 “W2 winding Output” ("No reactor at W2”の場合はその一部）を示す。

CC レス出力は, 発電機回転数 $360 \mathrm{rpm}$, および $600 \mathrm{rpm}$ 付近で理想 3 乗曲線との大きな乘離が見られる。また, W2 巻線にリアクトルを接続しない場合は, 風車出力よりも大 きな出力となっている。このように，リアクトル 2 に飽和 リアクトルを用いない場合には, Fig. 5 の CCレス入出力 特性イメージに対応した出力特性となる。

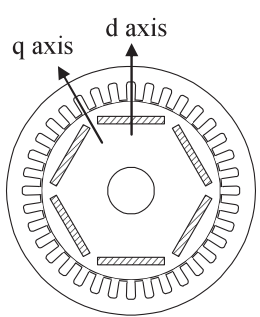

Fig. 14. Cross-section of IPM.

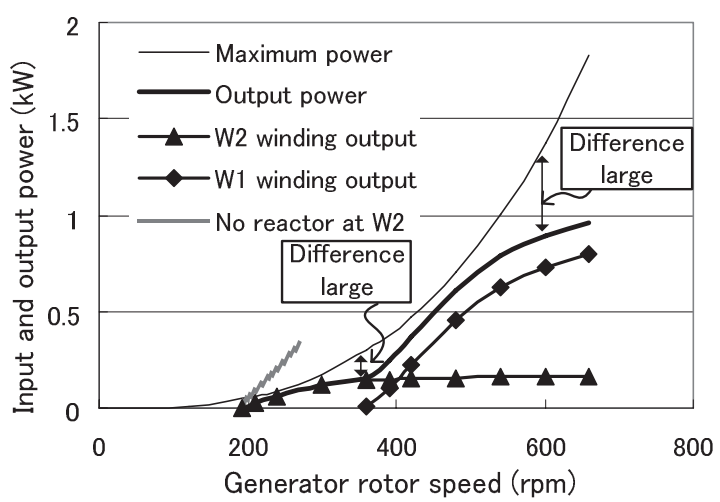

(a) No saturation reactor

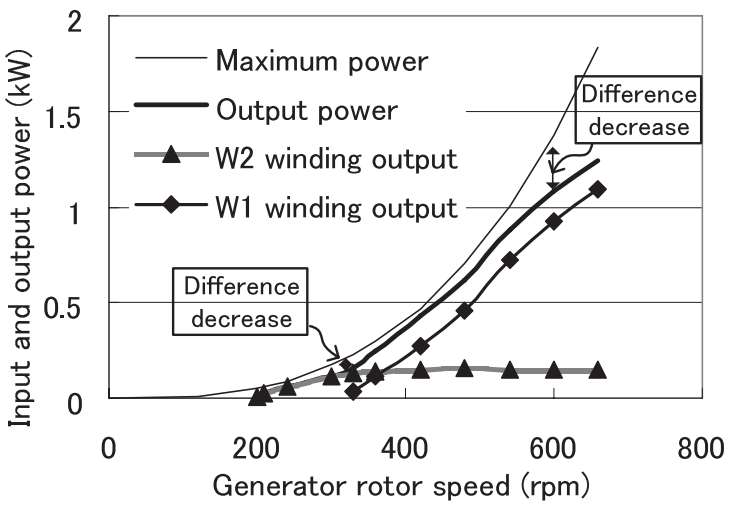

(b) Saturation reactor at $\mathrm{W} 1$ winding

Fig. 15. Characteristic discussion of CC-less.

そこで，Fig. 6 に示すような特性を持つ飽和リアクトル の接続による改善を解析した。その結果，前記 CCレス方 式確認装置と異なり, 巻線 W2 よりも巻線 W1 に接続する ほうが， 3 乗出力特性により近似することが分かった。

Fig. 15(b)にW1 巻線に飽和リアクトルを接続した場合 の解析結果を示す。W1 巻線が発電を開始する発電機回転 数を $330 \mathrm{rpm}$ (No saturation reactor では $360 \mathrm{rpm}$ ) 付近に 変更し, W2 巻線には非飽和リアクトルを接続した。発電 機回転数 $330 \mathrm{rpm}$ ，および $600 \mathrm{rpm}$ 付近で, Fig. 15(a) と比 べて, 理想 3 乗曲線との乘離を減少させた CC レス出力と なっている。

Fig. 16 にC レス発電機の各巻線出力電流解析結果を示 す。困において, 各巻線に単独で電流を流す場合 (“...only”) に比べて，CCレス動作時すなわち同時に流す場合（“2 winding...”）は各巻線とも電流が減少する。

この現象は, 発電機内部インダクタンスおよびリアクト ルにより各巻線電流が遅れ電流となり, この遅れ電流の無 


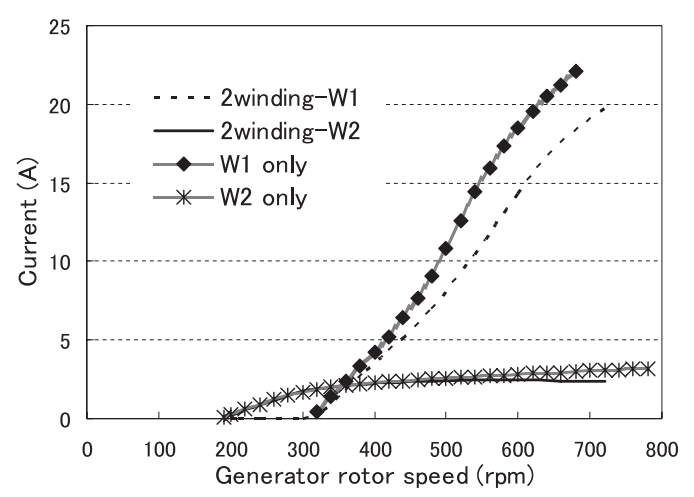

Fig. 16. Current of CC-less Generator.

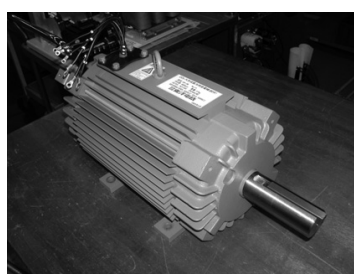

(a) CC-less generator

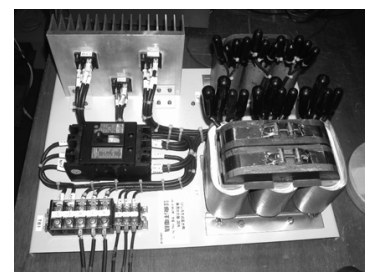

(b) direct output panel
Fig. 17. Generator and direct output panel.

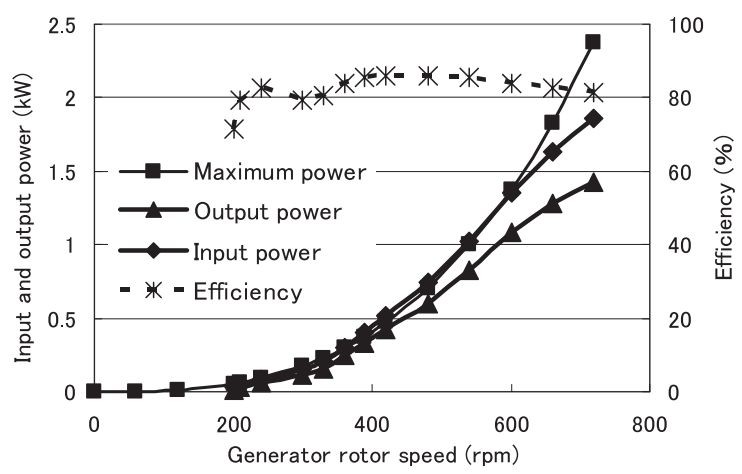

Fig. 18. Input and output power characteristic of $2 \mathrm{~kW}$ CC-less.

効分による固定子鎖交磁束の減少が相互に影響して，各巻 線の誘起電圧が減少したことが原因である。この力率の悪 い電流のために，新設計する場合には CCレス発電機の固 定子スロット面積を大きくして，コイル断面積を大きくし て銅損を小さくしなければならず，発電機は 2 割程度重く なることが予想される。

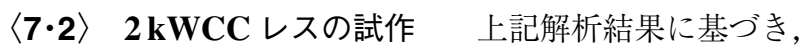
$2 \mathrm{kWCC}$ レスを試作した ${ }^{(7)}$ 。

この CC レスの仕様は $680 \mathrm{rpm}, 2 \mathrm{~kW}$ 発電機入力, 始動 トルク $1.1 \mathrm{~N}-\mathrm{m}$, 負荷としての直流電源電圧 $48 \mathrm{~V}$ である。 発電機は, $3 \phi, 6 \mathrm{P}, 36$ スロット, コア外径： $\phi 175$, ネオジ ウム磁石を使用した。

Fig. 17 に $2 \mathrm{kWCC} レ$ スの発電機, 直流出力盤をそれぞれ 示す。直流出力盤は，リアクトル，ブレーカおよび整流器 の受動素子のみで構成される。

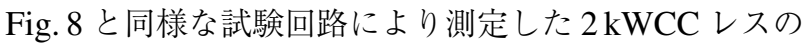
入出力特性を Fig. 18 に示す。横軸に発電機回転数, 縦軸に

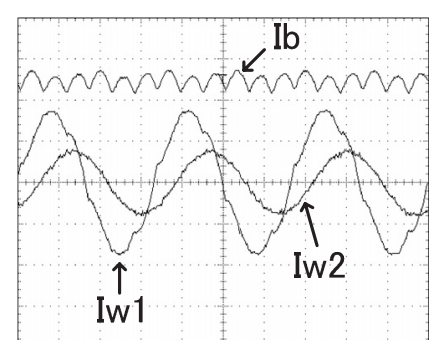

Fig. 19. Current wave form at CC-less.

入出力, 効率および参考に風車最大出力曲線を示す。CCレ ス入力が風車最大出力曲線に近似した特性となることが確 認できる。

Fig. 18 の実験結果の “Output power” は, Fig. 15(b) の解 析結果の“Output power”とほぼ一致している。

$\mathrm{CC}$ レス直流出力の効率は, 発電機入力に対して, ほ

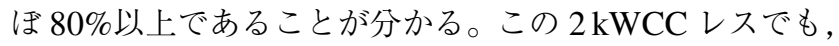
$\langle 4 \cdot 2\rangle$ 節で述べた方法で, 出現頻度の高い低風速域での効

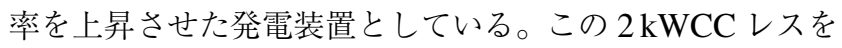
種々の風車に適用した場合のフィールドデータについては, まとまり次第報告する。

Fig. 19 は, Fig. 4 の主回路構成に記す発電機巻線 W1 の 電流 Iw1 と巻線 W2 の電流 Iw2, およびそれらを整流して 並列接続した直流出力電流 Ib の波形を示す。発電機回転数 は Fig. 18 の $450 \mathrm{rpm}$ 付近であり, 電流 Iw1 と電流 Iw2 は 発電機固定子の同一スロットに納められた巻線の電流波形 である。電流 Iw2 はリアクトル 2 のインダクタンス值が大 きいために, 電流 Iw1 よりも大きな遅れとなり, より力率 の悪い電流になっている。従って, 巻線 W2 の断面積は, 電流 Iw2 の有効分の大きさに比べて, 大きくしなければな らない。

\section{8. 風車と $\mathrm{CC} レ ス の$ 整合状態の変更}

CCレスは，CCレスと接続される負荷としての直流電源 電圧值または風車と発電機のギア比を変更すると, 風車と の整合状態が大きく変化する ${ }^{(7)}$ 。

Fig. 20 は，風車出力と CCレス入力との整合を説明する ための図であり, (a) は発電機入力, (b) は発電機卜ルクで示 したものである。Fig. 20(a) および (b) の，それぞれの“A” および “B” 点は同一動作状態を示す。例えば，風速 $10 \mathrm{~m} / \mathrm{s}$ で, 整合が取れているときは $\mathrm{A}$ 点で運転されるので, 風速 $10 \mathrm{~m} / \mathrm{s}$ での風車最大出力が得られる (“Matching”)。

整合状態から直流電圧值のみを設計值（Vdc）の 1.5 倍 程度にすると, 動作点が右にシフトして B 点で運転され, 風速 $10 \mathrm{~m} / \mathrm{s}$ での最大出力よりも2 割程度の出力減少となる (“Output decrease”)。逆に, 直流電圧值のみを半分程度に すると, 動作点が左にシフトするので, 風車は失速状態と なり，加速しないので出力が得られない(“Stall”)。

その他, 整合状態からギア比のみを増加すると, 動作点 は失速の方向にシフトし, ギア比のみを減少すると, 出力 


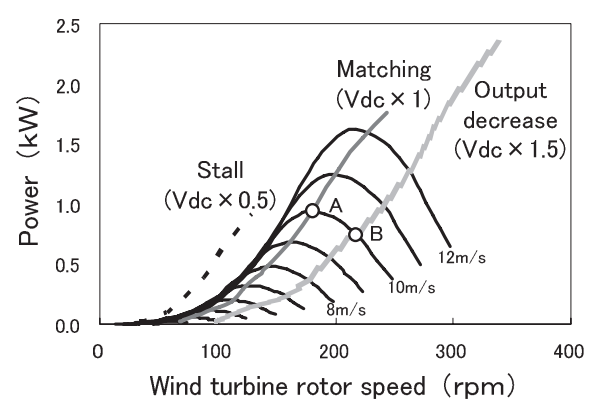

(a) Power

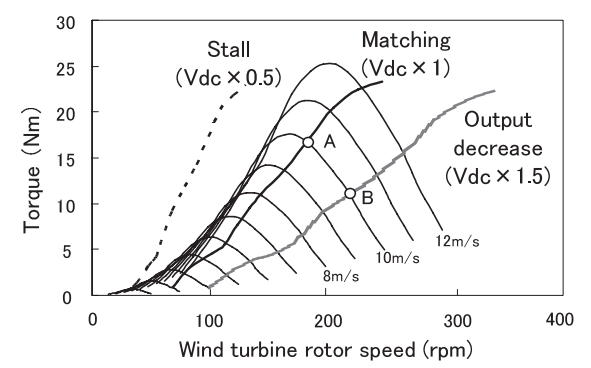

(b) Torque

Fig. 20. Matching between wind turbine and CC-less.

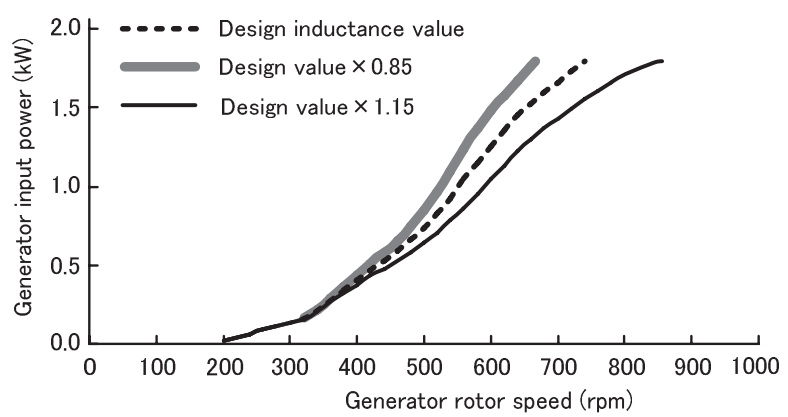

Fig. 21. Generator input power in changing tap.

減少の方向にシフトする。

Fig. 21 に, タップ付きリアクトルのタップ変更による発 電機入力の微小変更試験結果を示す。

このようにして, 風車性能との微妙な整合を図ることが できる。

これらの検討結果を裏返せば，負荷としての直流電源電 圧值，ギア比およびリアクトルのタップ変更を適正に設計 すれば, 風車性能の異なる風車に対しても, 同一 CCレス が適用可能であることを示している。

\section{9. まとめ}

風車と発電機の整合性に着目し, 風車最大出力取得面で, 風車との整合性が高い $\mathrm{CC} レ$ ス方式発電装置 (以下, $\mathrm{CC} レ$ スと称する。）の研究を行った。

研究に用いた発電機は, いずれも他用途電動機の巻線改 造品であるが,リアクトルと組み合わせた解析・検討によ りCCレスを試作して実験を行った。さらに，CCレスの 出力特性向上策および適用方法の検討に取り組み, 以下の ような成果が得られた。

（1）風車特性に整合するCCレスを研究し，フィール
ド実験結果より, CCレスが風車最大出力取得の面で整合 性が高いことが確認された。

（2）CCレスは，ギア比および直流電圧值を適正に選択 することにより, 風車出力特性が異なる種々の垂直軸型風 車に適用できることが分かった。

（3）整流方式に適した永久磁石型発電機の構造を明ら

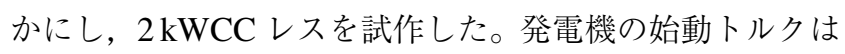
$1.1 \mathrm{~N}-\mathrm{m}$ となり, 始動トルクの小さな風車との組合せにお いては，ギアで増速しなければならないことを考えると大 きい值であり，多極化発電機が必要であることが分かった。

（4）CCレスで用いる発電機は, 遅れ電流が流れる多巻 線を有するために 2 割程度重くなる。しかし, 直線翼垂直 軸型風車では, 発電機は羽よりも下部に設置するために問 題とはならない。

インバータが不要なので, 初期コストの低減, および年 間発電量の増大の面でもCCレスは整合性が高いと思われ るので, 今後, これらの定量的な検討を行っていく。また, 水平軸型風車にも適用できると考えられるので, 今後, 実 験により有効性を確認していく。

CCレスの問題点として, 整流時の遅れ電流分による固 定子巻線と鎖交する磁束の減少がある。この磁束の減少を 回避し, 発電機の小型化を図る方法として, 進み電流分に よる磁束の増加が考えられる。

今後は, この進み電流分による磁束増加方法および多極 化の検討等を行い, 小型で始動トルクの小さいCCレス用 発電機を開発していく予定である。

(平成 20 年 2 月 8 日受付, 平成 20 年 6 月 25 日再受付)

$$
\text { 文 献 }
$$

(1) K. Seki, I. Usiyama, T. Nakagawa, S. Matymoto, and K. Sagara: "A Experimental About Matching of Wind Turbine and Generation System", The 20th Wind Energy Symposium, pp.160-163 (1998-11) (in Japanese) 関 和市・牛山泉·中川武彦・松本末晴・相良啓太 : 「小型風車と 発電機の整合性に関する実験的研究」, 第 20 回風力エネルギー利用 シンポジウム予稿集, pp.160-163 (1998-11)

(2) K. Sagara, K. Nomoto, Y. Sasahara, and K. Seki: "An Application of Straight Blade Non-Articulated Vertical Axis Wind Turbine Generation Systems", The 25th Wind Energy Symposium, pp.177-180 (2003-11) (in Japanese)

相良啓太・野本耕祐・笹原雄二郎・関 和市: 「直線翼垂直軸型風力 発電システムの実験的研究」, 第 25 回風力エネルギー利用シンポジ ウム予稿集, pp.177-180 (2003-11)

(3) H. Chikaraishi, Y. Hayashi, and N. Sato: "A Variable Speed Control of the Induction Generator without Speed Sensor for Wind Generation", T. IEE Japan, Vol.110-D, No.6, pp.664-672 (1990-6) (in Japanese)

力石浩孝・林 洋一・佐藤則明: 「風力発電用誘導発電機の速度セン サレス可変速制御」, 電学論 D, 110, 6, pp.664-672 (1990-6)

(4) T. Siota, T. Sano, and K. Seki: "Experimentally Optimizing the Matching between Straight Wing Non-Articulated Vertical Axis Wind Turbine Generation Systems and the Generator", Proc. of 2005 Annual Conference of Power \& Energy Society, IEE Japan, No.259 (2005) (in Japanese) 塩田 剛・佐野 孝・関 和市: 「直線翼垂直軸風力発電システム と発電機の整合性に関する研究」, 平成 17 年電気学会 B 部門大会, No.259 (2005)

(5) T. Siota, K. Tanaka, T. Isaka, and K. Seki: "A study of the Matching between Straight Wing Non-Articulated Vertical Axis Wind Turbine Generation Systems and the Generator", Proc. of JSES/JWEA Joint Conference, No.28 (2005) (in Japanese)

塩田 剛·田中啓太・井坂 勉·関 和市:「直線翼垂直軸型風車と 発電機の整合性に関する研究」, 2005 年太陽/風力エネルギー講演論 
文集, No.28 (2005)

(6) T. Siota, T. Isaka, and K. Seki: "A Development of the New Type Generating Unit for Wind Turbine Generator System", Proc. of 2007 Annual Conference of Power \& Energy Society, IEE Japan, No.392 (2007) (in Japanese) 塩田 剬 - 井坂 勉・関 和市:「新型風力用発電装置の開発」, 平 成 19 年電気学会 B 部門大会, No.392 (2007)

(7) T. Siota, T. Isaka, and K. Seki: "Experimentally Optimizing the Matching between Wind Turbine Generation Systems and the Generator", The 28th Wind Energy Symposium, pp.429-432 (2006-11) (in Japanese)

塩田 剛・井坂 勉・佐野 孝・関 和市:「風力発電システムと発 電機の整合性に関する実験研究」, 第 28 回風力エネルギー利用シン ポジウム予稿集, pp.429-432 (2006-11)
塩 田

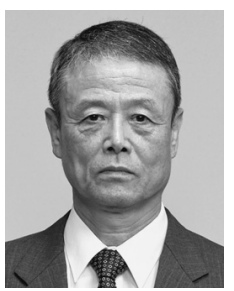

剛（正員） 1945 年 3 月 2 日生。1970 年 3 月九州大 学電気工学科卒業。同年東洋電機製造 (株) 入社。 技術研究所にて電気機械およびパワーエレクトロ ニクスの研究・開発に従事。現在は研究センター に所属して, 風力発電システム用発電機の研究 開発に従事。日本風力エネルギー協会会員。

\section{井坂}

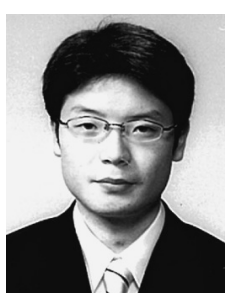

勉 (正員) 1980 年 10 月 19 日生。 2003 年 3 月千葉 工業大学工学部電気工学科卒業。2005 年 3 月同大 学大学院工学研究科電気工学専攻修士課程修了。 同年 4 月，東洋電機製造 (株)に入社。現在，研究 センター新技術リサーチグループに所属。主に, 風力用発電機の特性解析，特性実証試験に従事。 日本風力エネルギー協会, 日本太陽エネルギー学 会会員。

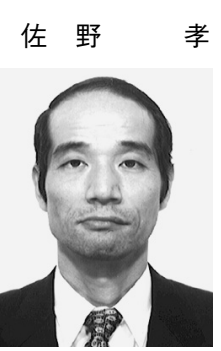

孝（非会員） 1950 年 9 月生。1974 年 3 月芝浦工業 大学工学部電気工学科卒業。1976 年 3 月芝浦工 業大学大学院工学研究科卒業。同年 4 月東洋電機 製造（株）入社。技術研究所を経て相模製作所鉄 道設計部にて主に車両用インバー夕装置の設計に 従事。現在, 研究センターセンター長。

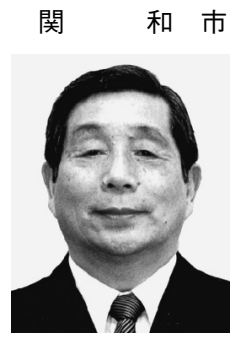

（正員） 1963 年東京大学宇宙航空研究所航空力 学部, 1976 年東海大学産業科学研究所, 1991 年 東海大学開発技術研究所, 1997 年東海大学総合科 学技術研究所。超音速空気力学, 応用空気力学, 大気拡散, 人力飛行機に関する研究, エネルギー 変換工学, 風車工学, 風力発電システムおよび新 エネルギー利用工学に関する研究を行っている。 現在, 日本風力エネルギー協会会長。教授。工学 博士。 